\title{
PEMANFAATAN TEKNOLOGI INFORMASI DAN KOMUNIKASI (TIK) DI TINGKAT PEMERINTAHAN DESA
}

\author{
Didit Praditya \\ Balai Pengkajian dan Pengembangan Komunikasi dan Informatika (BPPKI) Bandung \\ J1. Pajajaran No. 88 Bandung, HP. 08157723727. E-mail: didi012@kominfo.go.id \\ Naskah dikirim tanggal 4 Oktober 2014, direvisi tanggal 13 November, disetujui tanggal 27 November 2014
}

\section{THE UTILIZATION OF INFORMATION AND COMMUNICATION TECHNOLOGY (ICT) BY GOVERNMENT IN RURAL LEVEL}

\begin{abstract}
The central government often puts the village as an object, so the utilization of ICT programs only reached district or subdistrict area. Therefore the emergence of movement from villages that use internet, become a lesson that the initiative can be done from the bottom (village). The research was conducted through a case study by performing interviews and observations in Panjalu Village, Subdistrict Panjalu, Distric of Ciamis. Interview guidance is used to find out the condition of the village before and after the utilization of ICT. The result showed that Panjalu Village has held ICT training to the village employees and cadres. The utilization of ICT related to the business sector is quite complete and informative. The available website is used by the village government to promote agricultural, tourist sites, and handicrafts from SME (Small Medium Enterprises). In terms of e-government solution, the utilization of ICT largely are in the information stage, and a little bit are still in the interaction stage. The utilization of ICT in Panjalu Village is used to distribute or disseminate the information regarding the development activities.
\end{abstract}

Keywords: ICT, village, e-governments.

\begin{abstract}
Abstrak
Pemerintah pusat sering menempatkan desa sebagai objek, sehingga program-program pemanfaatan TIK terkadang hanya sampai pada tingkat kabupaten atau kecamatan. Oleh karena itu, munculnya gerakan dari desa yang memanfaatkan internet, menjadi pelajaran bahwa inisiatif dapat dilakukan dari bawah (desa). Penelitian dilakukan melalui studi kasus dengan melakukan wawancara dan observasi di Desa Panjalu, Kecamatan Panjalu, Kabupaten Ciamis. Pedoman wawancara digunakan untuk mengetahui kondisi desa sebelum dan setelah memanfaatkan TIK, penggunaan TIK, dan manfaat yang diperoleh oleh desa dari pemanfaatan TIK. Hasil penelitian menunjukkan bahwa Desa Panjalu telah mengadakan pelatihan TIK kepada perangkat dan kader desa. Penggunaan TIK terkait dengan dunia usaha sudah cukup lengkap dan informatif. Situs web yang tersedia digunakan pemerintah desa untuk mempromosikan hasil pertanian, lokasi wisata, dan hasil kerajinan produk dari usaha kecil menengah. Dalam hal solusi e-government, sebagian besar masih di tahap informasi, dan sebagian kecil berada di tahap interaksi. Pemanfaatan TIK di Desa Panjalu digunakan untuk menyebarluaskan atau diseminasi informasi mengenai kegiatan-kegiatan pembangunan.
\end{abstract}

Kata kunci: TIK, desa, e-government. 


\section{PENDAHULUAN}

Salah satu faktor yang menyebabkan kesenjangan digital antara wilayah perkotaan dan perdesaan adalah belum meratanya infrastruktur dan ketersediaan sumber daya manusia (SDM) teknologi informasi dan komunikasi (TIK), yang berpengaruh terhadap pemanfaatan TIK di tingkat desa. Akibat menghadapi berbagai permasalahan terkait pembangunan dan keterbatasan infrastruktur, maka penggunaan dan pemanfaatan TIK tidak dijadikan prioritas utama oleh pemerintahan desa. Namun di balik keterbatasan tersebut, muncul desa-desa yang mampu menggunakan dan memanfaatkan TIK guna mendukung kegiatan-kegiatan yang dilakukan di desa, sehingga mampu meningkatkan pembangunan desa tersebut.

Kesenjangan digital antara masyarakat perkotaan dan perdesaan merupakan salah satu masalah yang dihadapi negara berkembang. Kesenjangan tersebut dapat diakibatkan oleh berbagai faktor di antaranya kesenjangan infrastruktur antara kota dan desa, maupun tingkat kebutuhan masyarakat akan fasilitas dan perangkat TIK seperti telepon seluler, komputer, maupun internet, serta ketersediaan SDM TIK, yang berpengaruh terhadap pemanfaatan TIK di tingkat desa.

Kebijakan dan program-program pemerintah pusat sering menempatkan desa sebagai objek bukan sebagai subjek, programprogram pemanfaatan TIK hanya sampai pada tingkat kabupaten atau kecamatan. Oleh karena itu, dengan munculnya gerakan dari desa yang dapat menyelenggarakan pemeritahan secara baik dan mandiri, yang didukung dengan pemanfaatan TIK, menjadi pelajaran bahwa inisiatif tersebut dapat dilakukan dari bawah. Dengan demikian desa tersebut mampu melaksanakan pembangunan sesuai kebutuhan desa itu sendiri.

Di antara pemanfaatan TIK oleh desa misalnya: (1) Penggunaan piranti lunak sumber terbuka dalam kegiatan operasional (Mustika, 2011); (2) Penggunaan teknologi informasi dan komunikasi untuk berkomunikasi dan membangun jejaring antar desa (Desa Madusari, 2013); (3) Pembuatan website/blog guna keperluan diseminasi informasi kegiatan yang dilakukan oleh warga maupun aparat desa, meningkatkan penyebaran informasi sampai melewati batas wilayah (Gerakan Desa Membangun, 2014); (4) Penggunaan sistem informasi untuk melaksanakan pelayanan publik, memperkenalkan potensi desa maupun menyosialisasikan pembangunan desa (Jahja, 2012). Hal-hal tersebut dapat meningkatkan tata kelola pemerintahan yang baik dan mendukung kemandirian di tingkat desa.

Penelitian dilakukan di salah satu desa di Jawa Barat, yaitu Desa Panjalu, Kecamatan Panjalu, Kabupaten Ciamis, yang telah memanfaatkan TIK guna mendukung pembangunan dan kemandirian desa tersebut. Hasil penelitian diharapkan memberi masukan kepada berbagai pihak di antaranya, Direktorat Jenderal Aplikasi Telematika Kementerian Kominfo RI untuk mengetahui bagaimana pemanfaatan TIK di tingkat desa, desa-desa lain yang ingin menggunakan maupun memanfaatkan TIK sesuai dengan kebutuhan desa dalam kerangka pembangunan dan mendukung kemandirian desa, maupun pihak-pihak yang berkepentingan.

Penelitian berfokus pada pemanfaatan TIK di tingkat desa. Penggunaan atau pemanfaatan TIK dalam penelitian ini diartikan sebagai penggunaan/pemanfaatan TIK oleh desa untuk mendukung kegiatan pemerintah desa terkait pelayanan kepada masyarakat. Sangat penting untuk mengetahui pemanfaatan TIK di tingkat pemerintahan desa, karena desa merupakan suatu wilayah pemerintahan yang biasanya tertinggal dalam hal pemanfaatan TIK, dengan adanya inisiatif dari desa, studi mengenai pemanfaatan TIK di tingkat desa menjadi suatu hal yang perlu dilakukan. Pertanyaan penelitian adalah: Bagaimana pemerintah Desa Panjalu menggunakan TIK dalam menunjang kegiatan pemerintahan, dan apa manfaat-manfaat yang diperoleh dalam penggunaan TIK tersebut?

Tujuan penelitian adalah untuk mengetahui bagaimana pemanfaatan TIK di tingkat desa melalui studi di salah satu desa di 
Jawa Barat yang telah memanfaatkan TIK untuk mendukung kegiatan pembangunan desa tersebut, yaitu Desa Panjalu.

\section{LANDASAN KONSEP}

\section{Penelitian Terdahulu}

Di level strategis, penelitian mengenai implementasi TIK untuk meningkatkan kualitas hidup masyarakat perdesaan yang dilakukan oleh Fathoni (2010) menghasilkan kesimpulan bahwa upaya untuk meningkatkan kualitas hidup masyarakat di perdesaan secara optimal melalui pemanfaatan TIK perlu memerhatikan beberapa hal di antaranya membangun komitmen pemerintah terhadap pemanfaatan teknologi informasi dan komunikasi di perdesaan, pendekatan pengenalan, dan pemanfatan TIK dari sekolah, membangun berbagai jenis portal yang relevan dengan karakteristik dan potensi sumber daya yang terdapat di daerah masingmasing, serta membangun kemitraan dengan industri dan jasa telekomunikasi. Selain itu, penelitian mengenai TIK di tingkat desa misalnya penelitian tentang literasi TIK masyarakat desa pantai yang dilakukan oleh Siswanto (2012) menunjukkan bahwa tingkat literasi TIK masyarakat desa akan berbedabeda sesuai dengan letak geografis desa tersebut.

Selanjutnya, penelitian yang dilakukan oleh Santoso (2011) mengenai program pembangunan telecenter di perdesaan (sebagai salah satu wujud pemanfaatan TIK) yang dilaksanakan oleh UNDP-Bappenas menunjukkan bahwa masyarakat desa sebenarnya membutuhkan telecenter, namun harus berfungsi sosial yang berarti mengutamakan tujuan sosial, misalnya membantu mengentaskan kemiskinan masyarakat dengan menyediakan akses informasi dan turut mengembangkan UKM. Namun berbagai masalah dihadapi yaitu: kurangnya kesadaran masyarakat terhadap potensi yang berada di desanya sendiri, kurangnya pengetahuan/pemahaman manajemen pemasaran berbasis internet, perbedaan persepsi antara masyarakat dengan pengurus tentang telecenter, serta kurang adanya kerja sama dengan berbagai lembaga lain yang berwenang seperti Kementerian Pertanian yang dapat membantu bidang pertanian serta Kementerian Perindustrian yang menangani UKM dalam mendayagunakan telecenter di desa.

\section{Desa dan Pemerintahan Desa}

Menurut Undang-Undang No. 6 Tahun 2014 tentang Desa, bahwa desa adalah kesatuan masyarakat hukum yang memiliki batas wilayah yang berwenang untuk mengatur dan mengurus urusan pemerintahan, kepentingan masyarakat setempat berdasarkan prakarsa masyarakat, hak asal usul, dan/atau hak tradisional yang diakui dan dihormati dalam sistem pemerintahan Negara Kesatuan Republik Indonesia. Sedangkan pemerintahan desa adalah penyelenggaraan urusan pemerintahan dan kepentingan masyarakat setempat dalam sistem pemerintahan Negara Kesatuan Republik Indonesia, pemerintah desa diselenggarakan oleh kepala desa atau yang disebut dengan nama lain dibantu perangkat desa sebagai unsur penyelenggara pemerintahan desa.

\section{E-Government}

Terdapat beragam definisi $e$ government, namun terdapat beberapa kesamaan yaitu melibatkan penggunaan teknologi informasi dan komunikasi (TIK), khususnya internet untuk meningkatkan penyampaian layanan pemerintahan kepada masyarakat, bisnis (dunia usaha), dan instansi lainnya. E-government memungkinkan masyarakat untuk dapat berinteraksi dan menerima layanan dari pemerintahan lokal, daerah, maupun pusat selama 24/7 (24 jam sehari 7 hari seminggu) (Palvia dan Sharma, 2007). Penggunaan TIK oleh pemerintahan desa terkait dengan konsep e-government, namun dalam lingkup yang lebih kecil yaitu ruang lingkup desa. Gambaran dari solusi $e$ government ditunjukkan pada tabel 1. 
Tabel 1

Solusi e-Government

\section{Gambaran Solusi e-Government}

\begin{tabular}{|c|c|c|c|}
\hline & Government to Citizens & Government to Business & $\begin{array}{c}\text { Government to } \\
\text { Government }\end{array}$ \\
\hline $\begin{array}{l}\text { Tahap 1: } \\
\text { Informasi }\end{array}$ & $\begin{array}{l}\text { informasi lokal/nasional (visi } \\
\text { misi dan struktur organisasi, } \\
\text { alamat, nomor telepon, } \\
\text { undang-undang, peraturan, } \\
\text { regulasi, berita pemerintahan). }\end{array}$ & $\begin{array}{l}\text { informasi bisnis, alamat, } \\
\text { nomor telepon, jam kerja, } \\
\text { undang-undang, peraturan, } \\
\text { regulasi terkait bisnis. }\end{array}$ & $\begin{array}{l}\text { knowledge base (intranet), } \\
\text { knowledge management } \\
\text { (LAN). }\end{array}$ \\
\hline $\begin{array}{l}\text { Tahap 2: } \\
\text { Interaksi }\end{array}$ & $\begin{array}{l}\text { mendownload form dari situs } \\
\text { web pemerintah, dapat mengisi } \\
\text { form, } e \text {-mail, grup diskusi } \\
\text { (forum), poling, kuisioner, dan } \\
\text { sebagainya. }\end{array}$ & $\begin{array}{l}\text { mendownload form dari situs } \\
\text { web, dapat mengisi form, } e- \\
\text { mail, , dan sebagainya. }\end{array}$ & $\begin{array}{l}\text { e-mail, knowledge database } \\
\text { interaktif, penanganan } \\
\text { complain. }\end{array}$ \\
\hline $\begin{array}{l}\text { Tahap 3: } \\
\text { Transformasi }\end{array}$ & $\begin{array}{l}\text { Situs web yang telah } \\
\text { dipersonalisasi dengan akun } \\
\text { personal yang terintegrasi } \\
\text { untuk semua layanan. }\end{array}$ & $\begin{array}{l}\text { Situs web yang telah } \\
\text { dipersonalisasi dengan akun } \\
\text { personal yang terintegrasi } \\
\text { untuk semua layanan bisnis. }\end{array}$ & Basis data terintegrasi. \\
\hline
\end{tabular}

Sumber: Backus dalam Palvia dan Sharma (2007).

Tabel 2

Subkategori Model E-Government

\begin{tabular}{|c|c|c|c|c|}
\hline Komunikan & Konten & Karakteristik & Definisi & Contoh \\
\hline $\begin{array}{c}\text { Government to } \\
\text { Government }\end{array}$ & Informasi dan & $\begin{array}{l}\text { Komunikasi, koordinasi, } \\
\text { standarisasi }\end{array}$ & $e$-Administration & $\begin{array}{l}\text { Pembangunan dan } \\
\text { penggunaan data } \\
\text { warehouse yang } \\
\text { sama }\end{array}$ \\
\hline $\begin{array}{c}\text { Government to } \\
\text { Citizen }\end{array}$ & $\begin{array}{l}\text { Layanan } \\
\text { pemerintah }\end{array}$ & $\begin{array}{l}\text { Komunikasi, transparansi, } \\
\text { akuntabilitas, keefektifan, } \\
\text { keefisienan, standarisasi, } \\
\text { produktivitas }\end{array}$ & e-Government & $\begin{array}{l}\text { Website organisasi } \\
\text { pemerintah, } \\
\text { komunikasi } e \text {-mail } \\
\text { antara masyarakat } \\
\text { dengan aparat } \\
\text { pemerintah }\end{array}$ \\
\hline $\begin{array}{c}\text { Government to } \\
\text { Business }\end{array}$ & & $\begin{array}{l}\text { Komunikasi, kolaborasi, } \\
\text { perdagangan (commerce) }\end{array}$ & $\begin{array}{l}e \text {-Government, } \\
e \text {-Commerce, } \\
e \text {-Collaboration }\end{array}$ & e-procurement \\
\hline
\end{tabular}

Sumber: Yildiz dalam Yildiz (2007).

Tabel 1 menunjukkan bahwa solusi $e$ government dibagi menjadi tiga tahap yaitu: tahap informasi, tahap interaksi, dan tahap transformasi. Di tahap informasi, pemerintah berperan sebagai penyedia informasi bagi masyarakat dan dunia usaha, hubungan antar pemerintah menerapkan knowledge base atau knowledge management melalui dukungan intranet/LAN. Di tahap interaksi, masyarakat maupun dunia usaha dapat berinteraksi melalui situs web pemerintah seperti mendowload form, mengisi form, berkomunikasi dengan e-mail, dan sebagainya. Untuk hubungan antarpemerintah, contoh solusi model $e$ - government, komunikasi melalui e-mail, tersedianya knowledge database yang interaktif, dan sebagainya. Di tahap ketiga atau transformasi, situs web pemerintah dipersonalisasi dengan akun personal yang terintegrasi dengan semua layanan, serta mengintegrasikan basis data pemerintahan.

Subkategori dari model pengembangan e-government menurut Yildiz (2007) ditunjukkan oleh tabel 2. Subkategori model e-government menunjukkan komunikan, konten, karakteristik, definisi, dan contoh $e$ government yang terbagi menjadi hubungan antara pemerintah dengan pemerintah (government to government), hubungan antara 
pemerintah dengan komunitas atau masyarakat (government to citizen), serta hubungan antara pemerintah dengan dunia usaha (government to business).

\section{Manfaat Penggunaan TIK dalam E- Government}

Berdasarkan laporan OECD (The Organisation for Economic Co-operation and Development) dalam Darmawan (2011) terdapat beberapa manfaat e-Government, penggunaan TIK oleh pemerintahan memunculkan beberapa keuntungan, yakni:

1. Meningkatkan efisiensi, penggunaan TIK dapat meningkatkan efisiensi dalam berbagi data atau informasi di dalam maupun antarpemerintahan. Penggunaan TIK juga dapat meningkatkan efisiensi dalam pengumpulan (collecting) dan penyampaian (transmission) data, penyediaan informasi dan komunikasi. Begitu pula dalam memroses tugas dan operasi administrasi publik.

2. Meningkatkan pelayanan, penggunaan TIK dapat meningkatkan pelayanan terhadap masyarakat. Dalam menggunakan layanan publik, masyarakat tidak perlu mengetahui struktur dan hubungan kompleks dibalik layanan yang diberikan oleh pemerintah.

3. Membantu mencapai suatu kebijakan tertentu, penggunaan TIK dapat membantu menyosialisasikan kebijakan pemerintah kepada masyarakat sehingga pihak-pihak terkait dapat berbagi ide dan informasi terkait dengan suatu kebijakan tertentu.

4. Membantu kontribusi terhadap kebijakan ekonomi, penggunaan TIK dalam e-government dapat mengurangi korupsi, meningkatkan keterbukaan dan kepercayaan terhadap pemerintah. Pemerintah juga dapat melakukan penghematan melalui proses administrasi dan penyediaan informasi berbasis TIK. Begitu pula dengan kegiatan ekonomi di desa berbasis TIK (e-commerce maupun $e$ business) dapat di dukung dengan penggunaan TIK.

5. Meningkatkan kontribusi terhadap reformasi, penggunaan TIK telah mengubah atau mereformasi berbagai bidang, seperti: memerbaiki transparansi dan fasilitasi berbagi informasi.

6. Meningkatkan kepercayaan antara pemerintah dengan masyarakatnya, penggunaan TIK dapat meningkatkan good governance melalui peningkatan transparansi, mengurangi korupsi sehingga dapat meningkatkan kepercayaan masyarakat terhadap penyelenggara pemerintah. Begitu pula jika aspirasi dan pendapat masyarakat dapat difasilitasi ataupun ditampung dalam media berbasis TIK yang digunakan oleh pemerintah.

\section{METODE PENELITIAN}

Penelitian dilakukan melalui studi kasus dengan melakukan wawancara dan observasi di Desa Panjalu, Kecamatan Panjalu, Kabupaten Ciamis (secara purposif) yang dinilai telah memanfaatkan TIK dan internet guna mendukung pembangunan dan kemandirian desa. Penelitian akan mengeksplorasi pemanfaatan TIK dilakukan di tingkat desa dalam mendukung pembanguan dan kemandirian desa, memberikan gambaran mengenai pemanfaatan TIK di desa, dan menangkap keberhasilan desa tersebut dalam melakukan kegiatan pembangunan dengan dukungan TIK.

Model penelitian ditunjukkan pada gambar 1, peneliti melakukan wawancara dan observasi kepada narasumber mengenai kondisi desa sebelum pemanfaatan TIK, serta bagaimana kondisi setelah memanfaatkan TIK. Kondisi tersebut dilihat dari sisi sumber daya manusia dan proses pelayanan publik di dalam pemerintahan desa tersebut. 


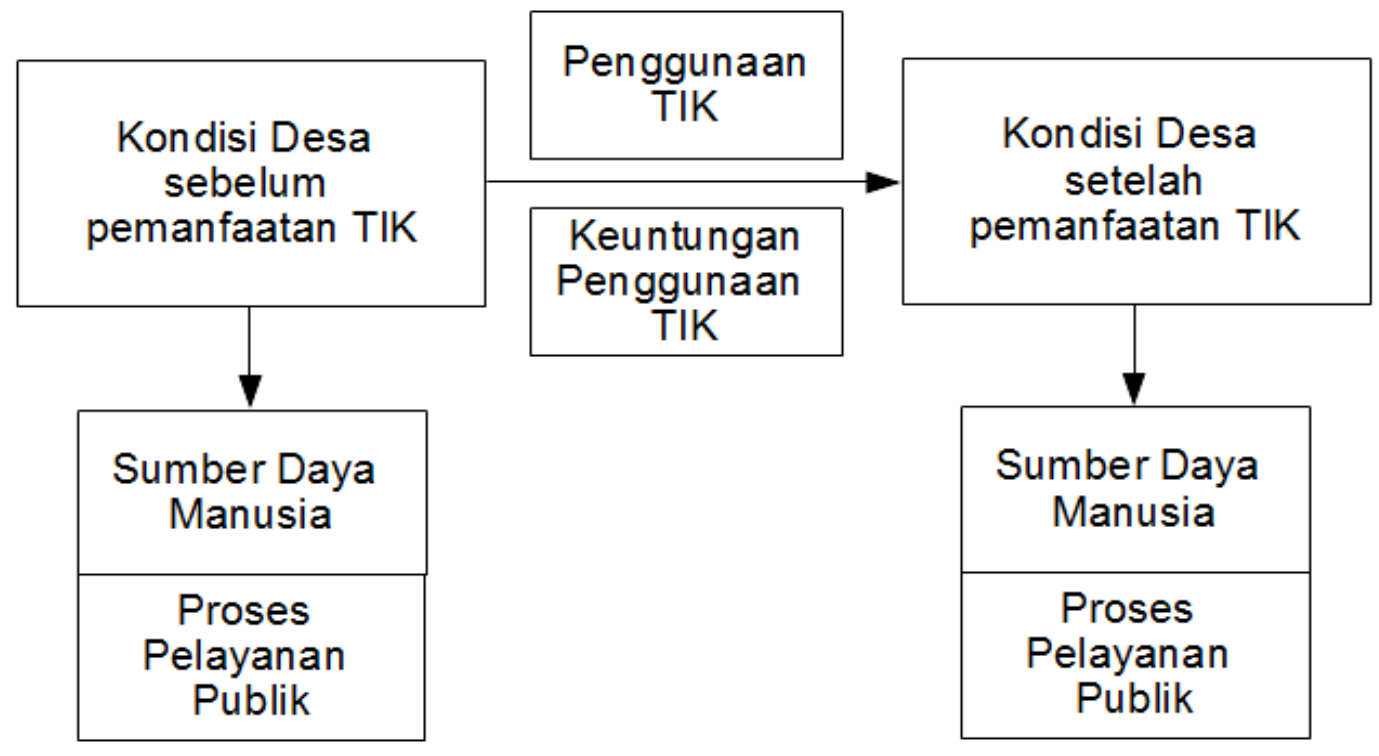

\section{Gambar 1 Model Penelitian}

Pedoman wawancara digunakan untuk mengetahui bagaimana kondisi desa sebelum dan setelah memanfaatkan TIK, bagaimana penggunaan TIK, dan manfaat apa yang diperoleh oleh desa dari pemanfaatan TIK.

Berdasarkan data/informasi yang dikumpulkan, dapat diketahui bagaimana kondisi desa sebelum dan setelah memanfaatkan TIK, bagaimana penggunaan dan manfaat apa yang diperoleh desa tersebut. Hasil observasi dan wawancara yang dikumpulkan berupa data kualitatif dan selanjutnya berdasarkan data tersebut dapat digambarkan pemanfaatan TIK di tingkat desa.

\section{HASIL PENELITIAN DAN PEMBAHASAN}

\section{Profil Desa Panjalu}

Desa Panjalu terletak di Kecamatan Panjalu, Kabupaten Ciamis, Provinsi Jawa Barat, salah satu desa di Provinsi Jawa Barat yang tergabung dalam Gerakan Desa Membangun (GDM), yang merupakan inisiatif kolektif desa-desa untuk mengelola sumber daya desa dan tata pemerintahan yang baik. GDM lahir sebagai kritik atas praktik pembangunan perdesaan yang cenderung dari atas ke bawah (top-down) dibanding dari bawah ke atas (bottom-up) yang menjadikan desa hanya sekedar menjadi objek pembangunan, bukan sebagai subjek pembangunan. Desa kurang diberi kewenangan dalam mengelola sumber daya yang ada di wilayahnya, karena undangundang telah menempatkan desa sebagai kesatuan wilayah hukum yang berhak mengatur rumah tangga sendiri (Gerakan Desa Membangun, n.d.).

\section{Sumber Daya Manusia Desa Panjalu}

Desa Panjalu mulai meningkatkan peran dan fungsi TIK dalam menunjang pemerintahan/pembangunan yaitu sejak tahun 2013 atau awal tahun 2014. Pada saat itu diselenggarakan pelatihan TIK dalam menunjang kegiatan Program Nasional Pemberdayaan Masyarakat (PNPM) Mandiri Perdesaan. Pelatihan TIK tersebut berawal dari kegiatan PNPM Mandiri Perdesaan yang harus diketahui dan disebarluaskan kepada masyarakat. Pelatihan tersebut diikuti oleh kader dan perangkat desa yang dimaksudkan agar kader dan perangkat desa dapat menyebarluaskan informasi melalui TIK kepada masyarakat mengenai kegiatankegiatan pembangunan yang dilakukan.

PNPM Mandiri Perdesaan atau Rural PNPM merupakan salah satu program 
pemberdayaan masyarakat yang mendukung PNPM Mandiri yang wilayah kerja dan target sasarannya adalah masyarakat perdesaan (PNPM Mandiri Perdesaan, n.d.). Salah satu tujuan khusus PNPM Mandiri adalah meningkatnya inovasi dan pemanfaatan teknologi tepat guna, informasi, dan komunikasi dalam pemberdayaan masyarakat (Program Nasional Pemberdayaan Masyarakat Mandiri, n.d.). Dengan demikian hal tersebut sejalan dengan pengembangan $e$ government dengan pemanfaatan TIK. Salah satunya adalah dilakukan dengan cara penyebaran informasi dan interaksi melalui situs web dalam mendukung kegiatan pembangunan dan pemberdayaan masyarakat desa.

Berdasarkan wawancara terhadap narasumber, yaitu Kepala Desa Panjalu, R. Haris Riswandi Cakradinata dan Sekretaris Desa, Dani Hamdani, mengatakan bahwa pada awalnya penggunaan TIK sudah berjalan dan digunakan dalam mendukung kegiatan perangkat desa, akan tetapi belum dilaksanakan secara optimal. Promosi potensi yang dilakukan belum gencar seperti yang dilakukan sekarang. Penggunaan TIK hanya sebatas menggunakan, dalam arti hanya untuk kegiatan operasional sehari-hari. Namun setelah dilakukan pelatihan TIK, beberapa kegiatan pemanfaatan TIK telah dilakukan di Desa Panjalu, yakni:

- Pengembangan SDM melalui pelatihan TIK kepada kader maupun perangkat desa.

- Penyebaran atau diseminasi beritaberita kegiatan pembangunan yang sedang dilaksanakan kepada masyarakat, sehingga meningkatkan pengetahuan masyarakat serta memudahkan perangkat desa dalam menyebarkan informasi kepada masyarakat.

- Peningkatan pengetahuan perangkat desa secara umum begitu juga dengan pengetahuan dan informasi mengenai pemerintahan, misalnya mengenai Undang-Undang Desa maupun pengetahuan lain.

Pemerintah Desa Panjalu memanfaatkan TIK dalam hal keterbukaan informasi publik seperti untuk penggalian informasi desa, publikasi kegiatan dan rencana pembangunan desa serta kegiatan yang berasal dari masyarakat umum. Menurut narasumber, dalam hal pemanfaatan internet dan pengelolaan website, beberapa manfaat yang dirasakan oleh masyarakat antara lain:

- Pelatihan TIK dalam rangka mengurangi rendahnya literasi TIK di Desa Panjalu.

- Masyarakat mengetahui kegiatankegiatan pembangunan yang dilaksanakan di desa.

- Masyarakat dapat dengan mudah mendapatkan informasi (anggaran, kebijakan, kegiatan, dan lain-lain).

- Masyarakat mengetahui informasi mengenai pelayanan publik di desa.

Dalam rangka meningkatkan sumber daya manusia, Desa Panjalu telah melaksanakan pelatihan TIK untuk kader dan perangkat desa. Pelatihan yang diselenggarakan secara rutin meningkatkan kemampuan perangkat desa terutama dalam mengimbangi perkembangan TIK yang sangat cepat. Pelatihan yang melibatkan masyarakat desa dapat meningkatkan literasi TIK masyarakat. Hal ini dapat dilaksanakan melalui pelatihan yang ditujukan terhadap komunitas-komunitas yang terdapat di masyarakat. Dengan inisiatif pemanfaatan TIK di tingkat desa dengan didukung literasi TIK perangkat dan masyarakat desa yang memadai, memungkinkan tujuan pembangunan dan pemberdayaan masyarakat desa dapat tercapai. Selain pelatihanpelatihan terkait TIK, peningkatan literasi TIK juga dapat dilakukan melalui peningkatan infrastruktur dan fasilitas (layanan) berbasis TIK di daerah (Sirait, 2009). Peningkatan infrastruktur juga dapat meningkatkan perekonomian masyarakat desa (Bachrein, 2010), sehingga kegiatan ekonomi akan terus berkembang jika didukung oleh pemanfaatan TIK dan internet. Desa Panjalu telah berhasil mendayagunakan TIK melalui dukungan program PNPM Mandiri Perdesaan, namun demikian penyelenggaran pelatihan terkait bidang TIK perlu terus dilakukan walaupun tanpa didukung pemerintah, sehingga peningkatan SDM akan 
terus berkelanjutan. Sinergis antara pengembangan SDM dan peningkatan infrastruktur dapat meningkatkan pemanfaatan TIK di tingkat desa.

Di sisi usaha (bisnis) menurut narasumber, sebelumnya penggunaan TIK oleh Desa Panjalu yang berkaitan dengan dunia usaha masih sedikit atau tidak ada sama sekali. Namun, manfaat-manfaat yang dapat dirasakan setelah menggunakan TIK dan mengembangkan website antara lain:

- Memudahkan hubungan antara petani dan pembeli dengan desa menjadi fasilitator yang memudahkan hasil pertanian dan perkebunan seperti jahe dipromosikan melalui situs desa, serta dapat meningkatkan kompetisi antar petani.

- Promosi produk hasil bumi dan kerajinan (UKM) lebih murah dari segi biaya (cost).

- Lokasi wisata lebih banyak dikunjungi oleh pengunjung melalui promosi pariwisata di situs desa, serta memudahkan promosi dan informasi mengenai penyelenggaraan festival seni budaya.

- Promosi produk-produk Usaha Kecil Menengah (UKM) maupun kuliner.

Penggunaan TIK atau internet yang dilakukan Desa Panjalu terkait dengan dunia usaha melalui situs web sebatas berita kegiatan atau media promosi mengenai hasil bumi, lokasi wisata, penyelenggaraan festival seni budaya, serta hasil kerajinan (UKM), dan sebagainya. Dari sisi informasi hal tersebut sudah cukup lengkap dan informatif, namun perlu dikembangkan fasilitas yang mendukung komunikasi dan kolaborasi antara pemerintah dengan dunia usaha. Seperti yang dikemukakan oleh Yildiz dalam Yildiz (2007), bahwa kategori pengembangan $e$ government yang terkait dengan dunia usaha atau G2B (Government to Business) memiliki karakteristik komunikasi, kolaborasi, dan perdagangan (e-commerce) dengan konten berupa informasi dan layanan pemerintahan. Situs web dapat digunakan pemerintah desa untuk mempromosikan hasil pertanian, lokasi wisata, hasil kerajinan (UKM) dan sebagainya, namun pemerintah desa juga perlu menyediakan layanan pemerintahan kepada dunia usaha misalnya menyediakan informasi mengenai pengurusan surat izin usaha, pengurusan surat izin usaha secara daring (online), atau menyediakan layanan $e$ commerce terhadap produk-produk yang dihasilkan oleh dunia usaha di desa.

\section{Proses Pelayanan Publik}

Penggunaan TIK yang berkaitan dengan pelayanan terhadap masyarakat di Desa Panjalu dilakukan untuk kegiatan operasional dalam mendukung pelayanan pemerintahan desa seperti: pengurusan administrasi kependudukan (Kartu Tanda Penduduk (KTP), Kartu Keluarga (KK), Surat Kelahiran, Surat Kematian, Surat Keterangan Catatan Kepolisian (SKCK), dan sebaginya), maupun dalam hal pengurusan perizinan, seperti Surat Keterangan Usaha, dan sebagainya. Namun dalam pelaksanaanya, masih belum dilakukan secara informatif maupun interaktif melalui pemanfaatan TIK melalui situs web. Walaupun demikian, pihak pemerintah desa menyatakan bahwa saat ini pihaknya sedang berupaya untuk mengembangkan pemanfaatan TIK (penggunaan aplikasi) khususnya untuk pelayanan kepada publik atau masyarakat.

Sesuai dengan solusi e-government yang dikemukakan oleh Backus dalam Palvia dan Sharma (2007), terdapat tiga tahap solusi e-government, yaitu tahap informasi, tahap interaksi dan tahap transformasi. Dalam tahap informasi, e-government menyediakan informasi kepada pihak terkait, yaitu dalam hal ini pemerintahan desa kepada pemangku kepentingan (masyarakat, dunia usaha, pemerintah). Misalnya informasi lokal/nasional (visi, misi, dan struktur organisasi, alamat, nomor telepon, undangundang, peraturan, regulasi, berita pemerintahan, dan sebaginya), sedangkan untuk informasi dunia usaha seperti informasi bisnis, alamat, nomor telepon, jam kerja, undang-undang, peraturan (regulasi terkait dunia usaha). Tahap interaksi memungkinkan pemangku kepentingan (stakeholder) berinteraksi dengan pemerintah melalui saluran komunikasi yang tersedia. Pemerintah menyediakan saluran interaktif 
yang melibatkan stakeholder seperti: mendownload form dari situs web, mengisi form online, e-mail, grup diskusi (forum), poling, kuisioner, dan sebagainya. Tahap ketiga atau tahap transformasi memungkinkan semua layanan pemerintahan yang didukung TIK terintegrasi dapat digunakan oleh setiap masyarakat yang memiliki akun personal.

Berdasarkan observasi, dalam hal solusi e-government yang dilakukan di Desa Panjalu sebagian besar masih di tahap informasi, dan sebagian kecil berada di tahap interaksi. Pemanfaatan TIK di Desa Panjalu digunakan untuk menyebarluaskan atau diseminasi informasi mengenai kegiatan-kegiatan pembangunan yang dilaksanakan. Untuk tahap interaksi, masyarakat memberi feedback kepada pemerintah desa melalui respon terhadap berita/informasi yang di posting di situs web desa. Selain situs web, pemerintah desa juga memiliki e-mail dan akun media sosial seperti facebook dan twitter untuk berinteraksi dengan masyarakat.

Kategori berita dan informasi yang dimiliki website Desa Panjalu telah cukup lengkap memberikan informasi mengenai kegiatan-kegiatan yang dilaksanakan. Namun, informasi mengenai pelayanan masyarakat seperti mengenai administrasi kependudukan, pengurusan perizinan, masih belum tersedia. Situs web yang dimiliki masih belum menerapkan tahap interaksi secara maksimal, tidak ada fasilitas pada situs web yang memungkinkan pemangku kepentingan (masyarakat) berinteraksi dengan pemerintah desa yang berkaitan dengan pelayanan masyarakat. Proses interaksi hanya dilakukan melalui respon (komentar) mengenai beritaberita yang diposting oleh pengelola situs web, melalui e-mail atau melalui media sosial.

Seperti yang dikemukakan oleh Budhirianto (2010), e-government dapat mempercepat interaksi antara pemerintah dengan masyarakat/pihak terkait, sehingga permasalahan-permasalahan publik dapat dilayani dengan cepat dan tepat. Untuk itu, situs web tidak hanya bersifat informatif saja, namun dapat interaktif maupun transaksional melalui peningkatan intensitas komunikasi dan ketertarikan masyarakat terhadap situs tersebut. Proses pelayanan publik yang merupakan kewajiban pemerintahan, sudah seharusnya difasilitasi dengan dukungan sumber daya TIK dan sumber daya manusia yang dimiliki.

\section{Model E-Government}

\section{Government to Citizen (G2C)}

Model e-government menggambarkan hubungan antara pemerintah dengan stakeholder melalui TIK, yaitu hubungan pemerintah dengan masyarakat (citizen), pemerintah dengan dunia usaha (business), dan hubungan antara pemerintah dengan sesama pemerintah (government). Untuk kasus di Desa Panjalu hubungan antara pemerintah dengan masyarakat atau komunitas selain melalui situs web (http://panjalu.desa.id/), juga dilakukan interaksi melalui e-mail, media sosial twitter melalui akun @desapanjalu dan facebook (https://www.facebook.com/desa.panjalu).

Kategori berita, artikel atau informasi yang disediakan di situs web Desa Panjalu, di antaranya mengenai kabar seputar Desa Panjalu, berita seputar pemilihan umum: Pilkades 2013, Pilkada Kabupaten Ciamis 2013, Pilkada Jabar 2013, dan Pemilu 2014. Berita, artikel atau informasi mengenai dusun-dusun di Desa Panjalu, tentang komunitas dan opini.

Hubungan melalui media sosial dapat meningkatkan intensitas komunikasi pemerintah dengan masyarakat sehingga pemerintah dapat dengan mudah dan cepat menangkap permasalahan atau keluhan masyarakat. Namun, hubungan interaktif melalui forum, e-mail, atau saluran formal (resmi) yang disediakan oleh desa juga diperlukan guna meningkatkan integritas dan keamanan.

\section{Government to Business (G2B)}

Hubungan pemerintah dengan dunia usaha (G2B) dilakukan pemerintah desa melalui penyebarluasan informasi mengenai hasil pertanian, potensi pariwisata, produkproduk UKM, festival/karnaval budaya, dan kuliner. Seperti yang telah disebutkan bahwa penggunaan TIK di Desa Panjalu terkait 
dengan dunia usaha melalui situs web sebatas berita kegiatan atau media promosi, belum ada sisi interaktif maupun transaksional atau transformasi. Kategori berita, artikel, atau informasi yang terkait dengan dunia usaha yaitu, kabar/berita kegiatan mengenai hasil pertanian, potensi pariwisata, festival seni dan budaya, produk-produk hasil UKM, kuliner dan berita, artikel atau informasi mengenai ekonomi kreatif.

\section{Government to Government (G2G)}

Dalam hal koordinasi secara informal, telah dilakukan kerjasama maupun koordinasi yang dilakukan oleh Desa Panjalu dengan desa-desa lain di Kabupaten Ciamis melalui forum komunitas TIK yaitu DedemIT (Desadesa Melek Informasi dan Teknologi). Komunitas DedemIT Ciamis terdiri dari para perangkat desa, pegiat pemberdayaan dan relawan TIK yang tergabung dalam gerakan desa membangun yang memunyai kepedulian untuk menyebarluaskan serta membangun tata kelola pemerintahan terbuka (open governance) melalui pengelolaan informasi perdesaan yang prima dengan menerapkan prinsip efektivitas, transparansi, dan akuntabel. Komunitas DedemIT Ciamis merupakan wadah gerakan sosial untuk mendorong terwujudnya pemerintah desa yang ramah dengan informasi dan teknologi yang murah, legal dan positif. Serta mendorong agar desa bisa memeroleh kedaulatan atas data dan sumberdaya yang ada untuk kesejahteraan (DedemIT, n.d.). Program kerja yang dilakukan oleh DedemIT yaitu:

- Pembuatan website desa secara gratis.

- Pelatihan pengelolaan Sistem Informasi Desa.

- Mengawal dan mengritisi pelaksanaan Undang-Undang Desa.

- Coaching clinic perangkat terbuka (open source).

- Pengelolaan aplikasi mitra desa.

- Pendidikan dan Pelatihan Pewarta Desa.

- Pendidikan Kader Pemerintah Desa

Hubungan antara pemerintah desa dengan instansi pemerintah vertikal maupun horizontal masih belum terkoneksi. Menurut model e-government (Yildiz, 2007), G2G memiliki karakteristik komunikasi, koordinasi, dan standarisasi yang dilakukan antarpemerintah yang berkaitan dengan konten informasi dan layanan pemerintah. Salah satu contoh penerapannya adalah pembangunan dan penggunaan data warehouse yang sama. Namun kondisi di Desa Panjalu, solusi e-government tersebut masih belum terkoneksi, baik dengan pemerintah daerah maupun pemerintah pusat. Interkoneksi atau hubungan terintegrasi tidak dilakukan oleh Desa Panjalu karena memandang hal tersebut merupakan tanggung jawab pemerintah pusat dalam membangun interkoneksi antar instansi pemerintah.

Hubungan antarpemerintah melalui jejaring yang terkoneksi dan terintegrasi melalui e-government sebaiknya dilakukan untuk memudahkan komunikasi dan koordinasi. Penggunaan standarisasi dan keamanan perlu diperhatikan dalam membangun hubungan tersebut. Desa yang merupakan suatu wilayah yang terbentuk dan dikelola berdasarkan prakarsa masyarakat desa itu sendiri (Undang-Undang No. 6 Tahun 2014 tentang Desa), memiliki karakteristik yang berbeda dengan desa lainnya, oleh karena itu diperlukan komunikasi dan koordinasi, jejaring atau forum komunikasi dengan desa-desa lainnya.

\section{PENUTUP}

\section{Simpulan}

Desa Panjalu telah menggunakan TIK untuk meningkatkan interaksi dengan masyarakat, terutama dalam melakukan penyebaran atau diseminasi berita-berita kegiatan pembangunan yang sedang dilaksanakan kepada masyarakat. Hal ini ditunjang dengan melakukan pelatihan dan menambah pengetahuan terkait TIK. Dari sisi SDM beberapa manfaat yang diperoleh oleh Desa Panjalu antara lain: (1) Mengurangi rendahnya literasi TIK masyarakat melalui pemanfaatan TIK; (2) Masyarakat mengetahui kegiatan-kegiatan pembangunan yang dilaksanakan di desa; (3) Masyarakat 
dapat dengan mudah mendapatkan informasi (anggaran, kebijakan, kegiatan, dan lain-lain); (4) Masyarakat mengetahui informasi mengenai pelayanan publik di desa.

Di sisi dunia usaha, penggunaan TIK yang dilakukan Desa Panjalu melalui situs web adalah penyebaran berita kegiatan atau media promosi mengenai hasil bumi, lokasi wisata, penyelenggaraan festival seni budaya, kuliner, serta hasil kerajinan (UKM). Hal ini memberi manfaat kepada Desa Panjalu, yaitu: (1) Memudahkan hubungan antara petani dan pembeli dengan desa menjadi fasilitator dan dapat meningkatkan kompetisi antar petani; (2) Promosi produk hasil bumi dan kerajinan (UKM) lebih murah dari segi biaya (cost); (3) Lokasi wisata lebih banyak dikunjungi melalui promosi pariwisata di situs desa; (4) Memudahkan promosi dan informasi mengenai penyelenggaraan festival seni budaya dan kuliner di Desa Panjalu.

Penggunaan TIK yang berkaitan dengan pelayanan terhadap masyarakat di Desa Panjalu dilakukan untuk kegiatan operasional dalam mendukung pelayanan pemerintahan desa maupun dalam hal pengurusan perizinan. Namun dalam pelaksanaanya, masih belum dilakukan secara informatif maupun interaktif melalui pemanfaatan TIK melalui situs web. Walaupun demikian, pihak pemerintah desa menyatakan bahwa saat ini pihaknya sedang berupaya untuk mengembangkan pemanfaatan TIK (penggunaan aplikasi) khususnya untuk pelayanan kepada publik atau masyarakat.

Dalam hal solusi e-government yang dilakukan di Desa Panjalu sebagian besar masih di tahap informasi, dan sebagian kecil berada di tahap interaksi. Pemanfaatan TIK atau internet di Desa Panjalu digunakan untuk menyebarluaskan atau diseminasi informasi mengenai kegiatan-kegiatan pembangunan yang dilaksanakan.

\section{Saran}

Pelatihan terkait TIK yang diselenggarakan secara rutin dan melibatkan masyarakat akan membantu meningkatkan literasi TIK. Kegiatan tersebut dapat disertai dengan penyediaan fasilitas (layanan) untuk masyarakat berbasis TIK di Desa Panjalu.
Perlu dikembangkan fasilitas (layanan) yang mendukung komunikasi maupun kolaborasi antara pemerintah dengan dunia usaha, misalnya informasi/layanan pengurusan izin usaha dan jual-beli secara online (e-commerce).

Proses pelayanan publik melalui situs web sudah seharusnya difasilitasi dengan dukungan sumber daya TIK dan sumber daya manusia yang dimiliki.

Situs web desa tidak hanya bersifat informatif saja, namun harus interaktif maupun transaksional melalui peningkatan intensitas komunikasi dan ketertarikan masyarakat.

Hubungan interaktif melalui forum, $e$ mail, atau saluran formal (resmi) perlu disediakan oleh Desa Panjalu guna meningkatkan integritas dan keamanan.

Meningkatkan komunikasi dan koordinasi, jejaring atau forum komunikasi dengan pemerintah maupun desa lainnya.

\section{DAFTAR PUSTAKA}

\section{Jurnal:}

Bachrein, Saeful. (2010). Pendekatan Desa Membangun di Jawa Barat: Strategi dan Kebijakan Pembangunan Perdesaan. Jurnal Analisis Kebijakan Pertanian, Volume 8 No. 2, Juni 2010, hal. 133149.

Budhirianto, Syarif. (2010). Efektivitas EGovernment Dalam Melaksanakan Fungsi Pelayanan Publik di Provinsi Jawa Barat dan Banten.Jurnal Penelitian Komunikasi, Vol. 13 No. 2 Tahun 2010, Departemen Komunikasi dan Informatika RI Badan Penelitian dan Pengembangan Komunikasi dan Informatika Bandung, hal. 55-70.

Darmawan, Ikhsan. (2011). E-Government: Studi Pendahuluan di Kabupaten Sragen. Proceeding Simposium Nasional Otonomi Daerah, LAB-ANE FISIP Untirta, hal. 69-75.

Jahja, Ranggoaini. et. al. (2012). Sistem Informasi Desa: Sistem Informasi dan Data Untuk Pembaruan 
Desa. Yogyakarta: COMBINE Resource Institution (CRI).

Palvia, Shailendra C. Jain dan Sharma, Sushil S. (2007). E-Government and EGovernance: Definitions/Domain Framework and Status around the World. Di dalam Agarwal, Ashok, et al (eds.) Foundations of E-government. $5 T H$ International Conference On EGovernance. Hyderabad, hal. 1-12.

Sirait, Emyana R. E. (2009). Literasi Teknologi Informasi dan Komunikasi (TKI) di Kalangan Pejabat Pemerintah Daerah Provinsi Bengkulu Tahun 2007.Widya Riset Vol. 12 No. 3 Tahun 2009, Lembaga Ilmu Pengetahuan Indonesia, Jakarta, hal. 103-109.

Siswanto, Sudji. (2012). Literasi Teknologi Informasi dan Komunikasi (TIK) Masyarakat Desa Pantai. Jurnal Studi Komunikasi dan Media, Vol. 16 No. 2 (Juli-Desember 2012). hal. 81-110

Yildiz, Mete. (2007). E-government research: Reviewing the literature, limitations, and ways forward. Government Information Quarterly 24 (2007), pp. 646-665.

\section{Internet:}

Desa Madusari. (2013). Madusari Bergabung Dalam Jejaring Gerakan Desa Membangun.Tersedia di $<$ http://madusari.desa.id/madusaribergabung-dalam-jejaring-gerakandesa-membangun/>.diakses September 2014.

DedemIT. (n.d.). Siapa Kami. Tersedia di $<$ http://ddemitciamis.web.id/siapakami/.>. diakses 28 Agustus 2014.

Fathoni. (2010). Strategi Implementasi Teknologi Informasi dan Komunikasi untuk Meningkatkan Kualitas Hidup Masyarakat Pedesaan di Indonesia.Seminar Nasional VI, 3 Juli 2010, Yogyakarta.Tersedia di <http://eprints.unsri.ac.id/2818/> .diakse s 3 Oktober 2014.

Gerakan Desa Membangun. (n.d). Siapa Kami. Tersedia di $<$ http://desamembangun.or.id/siapakami/>.diakses 28 Agustus 2014.

Gerakan Desa Membangun. (2014). GDM Siap Luncurkan Program Desa 2.0 di 100 Desa.Tersedia di <http://desamembangun.or.id/2014/08/g dm-siap-luncurkan-program-desa-2-0di-100-desa/>.diakses 1 September 2014.

Mustika, Maya Dewi. (2011). Desa Mandalamekar, Raih Kemandirian Teknologi dengan Open Source.Indonesian e-Learning Media.Tersedia di $<$ http://idelearning.com/desamandalamekar-raih-kemandirianteknologi-dengan-open-source/.> diakses 1 September 2014.

PNPM Mandiri Perdesaan.(n.d.).Tentang PNPM Mandiri-Perdesaan. Tersedia di $<$ http://www.pnpmperdesaan.or.id/?page=halaman\&story_ $\mathrm{id}=1>$.diakses 28 Agustus 2014.

Program Nasional Pemberdayaan Masyarakat Mandiri. (n.d.). Pengertian dan Tujuan.

Tersedia di $<$ http://www.pnpmmandiri.org/index.php?option=com_con tent $\&$ view $=$ article $\&$ id $=54 \&$ Itemid $=267$ $>$.diakses 28 Agustus 2014.

Santoso, Widjajanti M. (2011). Internet Masuk Desa, Rekam Jejak Pendirian Telecenter di Indonesia.Seminar Nasional Teknologi Informasi \& Komunikasi Terapan 2011 (Semantik 2011).Vol 1 No. 1 (2011).Tersedia di $<$ http://publikasi.dinus.ac.id/index.php/s emantik/article/view/164/126>.diakses [3 Oktober 2014]

\section{Perundangan:}

Undang-Undang RI Nomor 6 Tahun 2014 Tentang Desa. 